\title{
An Assessment of Students’ Recreation Participation
}

\author{
Meryem Akoğlan Kozak, Ece Doğantan \\ Anadolu University, Eskişehir, Turkey
}

\begin{abstract}
Recreational activities have psychological and social contributions in addition to individual recreation, and are extremely important especially for university students in development of healthy personality and establishing positive social relations. Continuation of a student's recreational activities after graduation, which has commenced at school, is quite significant in internalization of recreational awareness. The student's decision to continue a recreational activity in the future is dependent on the experiences of the student in this activity. This study aims to reveal detailed information about the recreation experiences of the students. Thus, the primary objective of the study was to access the information on preferred recreation activity categories, recreation experiences, and the intent to continue these activities. In the study, quantitative research approach was adopted and survey form was applied to a sample of 268 students who were registered to student clubs in the university. Factor analysis, correlation, and regression analysis were used in the analysis of the survey data. Result of the factor analysis conducted on the "Recreation Experience Preferences" (REP) scale items, it was determined that the scale was structured in seven dimensions of "physical exercise and rest," "learning about new and different objects and people," "leading and introspection," "achievement," “escape from personal-social pressures," "learning about culture, arts and nature," and "human relations" and REP scale could be used to assess recreational experiences as well as the determination of recreational preferences. The findings of the study determined that the students preferred social recreation activities the most, followed by cultural, artistic, and physical recreational activities. Student participation frequencies based on activity categories could be sorted as social, artistic, cultural, and physical, respectively. As the students' participation frequency in recreation activities increased, the experiences acquired increased as well. Thus, it was observed that as the frequency of participation in social, cultural, and artistic categories increased, the experiences in "learning about to nature, culture and art" and "escape from personal-social pressures" increased accordingly. The findings of the study determined that the dimensions of experience acquitted as a result of recreational activities of "leading and introspection" and "human relations" were effective on the intent of the students on sustaining the related recreational activity. Thus, applications that would help students to spend their leisure times in sustainable activities to become physically, mentally, and socially healthy individuals in the future and would develop their experiences in the dimensions of "leadership" and "human relations" should be prioritized.
\end{abstract}

Keywords: recreation experience, recreation activities, intention to continue

\section{Introduction}

Recreation, albeit related to individual needs, is a social concept and it is significant on especially the

Meryem Akoğlan Kozak, Ph.D., professor, Faculty of Management, Anadolu University.

Ece Doğantan, Ph.D. candidate, research assistant, Faculty of Management, Anadolu University. 
healthy personality development, ability to form positive social relations, and achievement of emotional vitality and energy of the youth that experience psychological and social growth. Thus, university students, who are at a significant phase of education process, in addition to gaining proficiency in their field of study, should achieve recreational experiences that would enable efficient use of their spare times. The manner students make use of their spare times and the recreational experiences they achieve as a result, are closely related to the opportunities provided for them. Although the family, the environment the family lives in, friendly relationships, and mass communication tools are effective on recreational activities, universities provide experiential environments where students could develop different areas of interest. Previously, there was a doubt that recreational activities did enrich the students culturally, develop their personal interest and orientations, affected their physical, mental and cognitive health. Today, recreation is considered as a significant part of the educational process in several countries (Karaküçük, 2008, p. 141). Thus, student clubs in universities organize various recreational activities by approaching the recreational services via organizational initiatives. These activities, by affecting the personality development of students, support their socialization as well as provide conditions to gain experiences that would be part of their whole lives.

Continuation of the recreation experiences after the graduation, which are shaped by various activities during participation in recreation, is quite important for the lifelong physical-mental health of the youth and a balanced social life (Kaba, 2009, p. 47). Thus, development of recreation in universities is considered as a significant part of lifelong education (Müftüler, 2008, p. 3). The objective of the study, therefore, is to determine the effects of the experiences Anadolu University students had as a result of recreation activities they participated on their intention to continue these recreation activities in the future. In addition to the main objective, it was also aimed to determine the participation frequencies of the students to recreational activities based on categories and to assess on which experience dimension these experiences were concentrated. The study is significant, since it provides consciousness for the students on recreation activities and guidance for practitioners in planning, development, and management of recreational experiences.

\section{Literature Review}

\section{Concept of Recreation and Its Categories}

Starting from the introduction of technology in human life, the individual, who became a part of a complex and immense work schedule, was in search for a way out of this stressful routine. This search caused humans to allocate their spare times remaining from the activities that were conducted to provide for their existence, in a planned or unplanned manner, for recreation that would replenish them physically and mentally (Günaydın, 2011, pp. 13-14). The word "recreation" has its roots in Latin recreatio, which means revitalization, recreation, or restructuring (Ozankaya, 1980, as cited in Karaküçük, 2008, p. 58). According to this fundamental approach meaning recreation, it is defined as replenishing, resting, and volunteer activities engaged in after compulsory duties and activities (Kraus, 1985). However, today, recreational activities are practiced not only for revitalization, but also for sightseeing, pleasure and entertainment, rest, health, education, socialization, to have different experiences, to get away from the daily routine, and self-realization (Driver, 1983; Köktaş, 2004, p. 126; Karaküçük, 2008, p. 58). Most of the recreation definitions in the literature are activity-centered. Thus, recreation is explained as volunteer participation of individuals in activities with an impulse of entertainment and satisfaction (Leitner \& Leitner, 2012, p. 4). According to another activity oriented approach, recreation is the participation of individuals, due to various motivational factors, to various activities 
indoors or outdoors, actively or passively, in urban areas or in the countryside (Karaküçük, 2008, p. 58). Ministry of Culture and Tourism defines recreation as activities that people engage during their free time, using their free time independent from compulsory work activities, to mend their physical strength and enrich their mental capacity, selected freely unlike compulsory activities, and meaning a change in physical and social environment (KTB, 1989, as cited in Günaydın, 2011, p. 20).

Recreational activities are realized voluntarily, in individuals' spare time, along with their personal preferences. These activities elected by the individuals freely and do not require compulsory attendance, could be practiced individually or in groups and they could be planned or unplanned. There is no specific limitation of space in recreational activities. These flexible activities could be practiced in all indoor and outdoor spaces and in all seasons and under all climate conditions (Karaküçük, 2008, pp. 71-75). Recreational activities are usually practiced in groups and individuals that take a role in these type of social groups enter into interactive relationships, and thus it could be argued that recreational activities play a significant role in socialization of the individual (Köktaş, 2004, p. 105). Especially the success of recreational activities conducted in groups is dependent on the leader and it is observed that group's structural characteristics and internal dynamics are effective in the achievement of the leaders (Kozak \& Yüncü, 2008, p. 74; Kozak \& Çakır, 2012). Recreational activities create a common language for all people and could be performed by people of all ages, gender, and social status (Leitner \& Leitner, 2012). As a result, recreation represents an experience that derives from the participation of individuals in recreational activities (McLean, Hurd, \& Rogers, 2005; Leitner \& Leitner, 2012). Individuals, as a result of these experiences gain personal and social characteristics (Köktaş, 2004, p. 9).

Recreation is a broad concept and differs from one culture to another and from one individual to other. This fact created different categorizations of recreation. For instance, Dumazedier (1968, p. 6) divided recreational activities into five main categories. These are: "physical," such as walking, sports, and traveling; "artistic," such as in being interested in different branches of fine arts; "practical/applied works," like handicrafts; "intellectual," such as reading and increasing one's knowledge; and "social," such as in entertainment and visits (as cited in Akınc1, 2011, p. 13). Akasen (1978), in additional to recreational features, divided recreation into different categories of commercial, social, international, aesthetic, physical, and forest recreation based on administrative purposes (as cited in Karaküçük, 1997, p. 70). Raghep (1989) created a more comprehensive categorization. He categorized the activities as "mass communications," such as watching TV and going to movie theaters; "cultural," such as in concerts, museums, opera, and ballet; "sports," like fitness, team, and individual sports; "social," such as in parties and visiting friends; "outdoor", such as picnic, hunting, and camping; and "hobbies," such as drawing, collecting, and photography (as cited in Kleiber, Walker, \& Mannel, 2011, p. 76). Another main grouping was implemented by Tribe (1995), dividing recreation basically into three categories. These are: "indoor recreational activities," such as listening to music, watching TV, and reading; "outdoor recreational activities," like participation in sportive activities, visiting various spaces, hobbies; "travel and tourism activities," such as in travelling to a place and lodging. According to Karaküçük (1997, pp. 68-69), categorization of the recreation is based on the individual's reasons for participation in recreational activities, individual's desires and tastes. Based on the reasons why an individual decides to participate in a recreational activity, an appropriate recreation type is created. Within these limitations, Karaküçük categorized recreation based on its purposes (leisure, cultural, social, sportive, touristic, and artistic) and based on various criteria (age, number of participants, time, space, and social). Hazar (2009, p. 30), similar to Karaküçük, asserted that criteria, such as purpose, space, and function should be utilized for categorization of 
recreation types, and divided recreation into six categories by utilizing the studies by Duncan (1954) and Akesen (1978). According to Hazar (2009), certain recreational activities belong to more than one category. For instance, activities, such as golf and kayaking could be evaluated under "outdoor recreation," which is located in spatial category; they belong to "sportive recreation" category located under functional recreation types as well.

In studies conducted with students, recreational activities are generally grouped as social, cultural, artistic, and physical. It was observed that the student clubs that form the sampling in this study included the following spheres of activity: "activities that improve and test knowledge and skills," such as tournaments, parlor activities, educational seminars, occupational training courses; "artistic" and "cultural" activities, such as dance, music, movies, theatre, and drawing; "physical activities," such as sports; "tourism and travel activities," such as excursions and tourism; and "social activities," such as volunteer social services. Within the scope of the activities of student clubs, the study was based on Dumazedier (1968) and Hazar's (2009) functional categories. Accordingly, activities were categorized under four main topics of physical, social, artistic, and cultural activities.

Physical recreation includes sportive activities performed indoors and outdoors. These are pool, river, lake, and sea activities, such as swimming, water sports, and spear fishing; mountain sports, such as trekking, climbing, hunting, and skiing; and sports like basketball, football, volleyball, tennis, table tennis, golf, gymnastics, and equestrianism. Social recreation includes activities for establishing and enforcing interpersonal relationships like attending meetings and parties, and making social calls. Social recreation develops and improves individuals' artistic skills and includes activities in several branches of fine arts. Activities that improve manual skills, such as cartoons, drawing, design and artistic activities, such as dance, movies, theatre, music, festivals, concerts, photography, fairs are under this category. Cultural recreation includes activities that improve and test knowledge and skills. All intellectual activities that improve and test knowledge, such as daily excursions and touristic trips, foreign language, computer and other occupational training courses and seminars, tournament intelligent games are considered within this context.

\section{Recreation Experience}

Although in spare time literature experience is generally used interchangeably for "activity," spare time behavior means so much more than activity (Manfredo, Driver, \& Tarrat, 1996, p. 189; Patterson \& Pegg, 2009, p. 257). According to Budruk and Stanis (2013, p. 52), participations of individuals in recreation are experiences that end with physiological, psychological, and social output in specific areas. McCool (2006, p. 3) explained the experience of recreation as a concept "that could be defined in various ways, but rather a more social psychological phenomenon affected by individuals' expectations, norms, individual's company in recreational area, and especially from the attitudes formed against the area during the visits." In brief, the experience of recreation occurs as a result of the meanings it has for the individuals, rather than the content of the activities. Thus, it could be argued that recreation experience carries different meaning for different individuals, in other words, differs from one person to another. For instance, an activity could be considered as work for one, while for another it could be a pleasant recreational activity (Ateca-Amestoy, Serrano-del-Rosala, \& VeraToscanoa, 2008, pp. 65-66). Experience is a hard to define concept and recreation experience is considered differently based on concepts, such as activity, assessment, perception, motivation, drive, and satisfaction. For instance, Müderrisoğlu et al. (2005), who approached the subject of experience and satisfaction 
in Turkey, in the study where the visitor profiles at Abant Natural Reserve were scrutinized, aimed to determine the general satisfaction levels of the visitors after their experiences. In another study that aimed to determine behavioral relationships between nature-based outdoor recreation and holiday tourism, experience preferences theory was utilized in explanation of outdoor recreational motives (Aşan, 2013, p. 5). On the other hand, Kozak and Metin (2014, p. 1121) mentioned recreational opportunity distribution (ROD) method that was developed to create opportunities for satisfaction of individuals' experience needs, and argued that this method especially created significant opportunities for realization of the experiences that people desired.

In the study, "Recreation Experience Preferences" (REP) scale, developed within the framework of REP was used to assess the experiences that the students had as a result of attending recreational activities. In certain studies, it was observed that REP scale was utilized to determine the benefits obtained as a result of participation in recreational activities (Shores \& Scott, 2007). The original tem pool of the REP scale consists of 328 expressions. It was identified that, in studies the scale was utilized, only the required expressions were used based on the context of the research (Hsieh, 2007, p. 24). Manfredo et al. (1996) demonstrated the validity and reliability of the scale in their meta-analysis study, which included 36 studies that utilized the REP scale. Thus, 26 expressions under seven dimensions were utilized in the REP scale, which was used to measure psychological, social, and physiological output related to the behavior of the students in the study. The reason why these dimensions were preferred was the fact that these dimensions were utilized in recreational studies conducted with students in the literature (McKenzie, 2011; Flood \& Parker, 2014), and these experience dimensions were related to the activities that the students participated in the clubs. The dimensions utilized in the REP scale were: "achievement," "human relations," "learning," "teaching and leadership," "insight," "physical exercise and leisure," and "escape from personal and social pressure."

As is known, recreation is a re-creation or restructuring activity (Kraus, 1985). In addition, it also means escape from daily routine, revitalization, and change. Students that participate in recreational activities could interrupt the classes they take routinely, and help ease the mental pressure off, thanks to the organizations they attend. Students that participate different recreational activities for different purposes gain an experience. Students that experience one or more recreational activities together have different recreational experiences. Based on this assumption, the following H1 hypothesis was developed in the study.

H1: "There is a significant relationship between the recreation categories the students participated and the experiences they gained."

\section{The Intent to Continue Recreational Experience}

Intent is defined as the determined probability for a behavior to be realized (Oliver, 1997, p. 23). Behavioral intent, accepted as an output of satisfaction process, is considered as a significant factor that explains the behavior of the individual through a strong intention to enact a behavior, whose outcome is previously known (Ajzen, 1991, as cited in Kaur \& Gupta, 2012, p. 245). Theory of Reasoned Action and Theory of Planned Behavior developed over the first, both identified that the closest element to behavior is the intent (Başaran, 2014, p. 66). It was conceived that intent, developed by the individual, occurs due to two different factors: individual and social. Personal factor identifies the positive or negative assessments of the individual to fulfill the behavior and expressed as the attitude developed against the behavior. Social factor that is effective on intent identifies the social pressure that the individual perceives on whether he or she should perform the related behavior and defined as the subjective norm (Ajzen, 1985, p. 12). Behavioral intent is 
frequently mentioned especially in the discipline of marketing. The intent of an individual to buy a product or service again from the same business consists of assessments and thoughts based on the individual's own experiences (Hellier et al., 2003, p. 1764). A similar approach is also accepted in recreation studies. According to scholars, activities are the main part of experiences. The choice of an individual for the next activity or the intent to continue the activity depends on the remembrance phase of the previous activity, therefore, on the experiences of the individual (Clawson \& Knetsch, 1966, as cited in Nikolaeva, 2012, p. 10).

There are studies in the literature that scrutinized the participation in sports activities and the intent to continue these activities. In a study, which determined that the attitudes of an individual towards behavior affected the intent and examined the participation in sports activities, it was determined that the most significant factor that affected the recreational behavior intent was the personal impediments (Alexandris \& Stodolska, 2004, p. 212). In another study conducted with skiers, coping strategies with the factors that prevent participation in skiing activities and the relationship with maintaining skiing were scrutinized. In the study, it was determined that if the cooping strategies were successful, these strategies would be effective on the intent to continue the activity (Alexandris, Kouthourisand, \& Girgolas, 2007, p. 648). In this study, recreational experiences of the students were accepted as a prerequisite factor for the continuation of the said activity, and the following hypothesis was formulated.

$\mathrm{H} 2$ : "Recreational experiences of the students are effective on the intent to continue the same recreation activities after graduation."

\section{Methodology}

The main objective of the study, is to determine the experiences Anadolu University students gained as a result of recreation activities they participated, and the effects of these experiences on their intention to continue these recreation activities in the future. Study results were considered significant, since they would help raise the consciousness of the students on recreational activities, and they would also guide the implementers in planning, development, and management of the recreational experiences of the students.

In the study, where a quantitative research approach was adapted, the survey method, which is a systematic data collection technique by directing questions to resource individuals that form a universe or a sample based on hypotheses determined on a specific subject, was utilized (Ekiz, 2009; Kozak, 2014). The survey form utilized consisted of four sections. In the first section, recreation activity types were asked in 10 items to assess the status of participation of the students in activities in their spare time, and the frequency of their participation in these activities. The participation frequencies of the students in these activities were measured using the frequency scale $(1=$ Do not agree; 2 = Seldom agree; $3=$ Agree; 4 = Frequently agree; and $0=$ Do not know/No opinion). In the second section of the survey form, scale expressions designed within the framework of REP were utilized to assess the experiences the students had as a result of participation in recreational activities (Driver, 1983). Scale expressions, selected from the item pool and adapted to Turkish, consist of 24 expressions that are classified under seven dimensions. However, since the activities that the students participated included "arts" and "culture" in addition to "nature," within the context of the study, the expressions of "I learned more about culture" and "I learned more about arts" expressions were added to the expressions in the "learning" dimension. Thus, in the second section there were a total of 26 scale expressions classified under seven dimensions. These expressions were assessed using a Likert-type scale ( 1 = Strongly disagree; 2 = Disagree; 3 = Agree; $4=$ Strongly agree; and $0=$ Do not know/No opinion). In the third section of 
the survey, five expressions were used to assess the intent of the students to continue recreational activities. The first four expressions were taken from the scale expressions used by Alexandris and Stodolska (2004), Kim, Chelladurai, and Trail (2007), and Kouthouris (2009) in their studies, and a fifth expression of "I plan to continue and improve the recreation activities that I participated in the club professionally after I graduate" was added to determine whether the students would continue the recreational activities professionally in the survey questionnaire form. In this section, similar to the second section, expressions were assessed using a Likert-type scale $(1=$ Strongly disagree; $2=$ Disagree; $3=$ Agree; $4=$ Strongly agree; and $0=$ Do not know/No opinion $)$. In the fourth section of the study, demographical questions such as age and gender, and questions on the length of experience for the activities the students participated were included.

Before the field application, surface validity and reliability of the survey questionnaire was tested by a pilot study conducted with 40 students, who were members of student clubs. The application implemented face-to-face, the participants were asked if the expressions were comprehensible, and as a result of the positive feedback received it was determined that the survey form was comprehensible and met the requirement of surface validity. Reliability tests conducted on the results obtained by the pilot application demonstrated that the experience scale internal consistency coefficient (Cronbach Alpha) was 0.959 intent to continue scale internal consistency coefficient was 0.725 . In other words, the scales were reliable. With the survey questionnaire that met the conditions for surface validity and reliability as a result of pilot application, the field application was commenced.

The sample of the study was determined as the 800 students with active participation based on the information obtained from student clubs coordination office. Survey field application was conducted both online on the Internet and face-to-face. The link for the online survey questionnaire was e-mailed to student club presidents and they were asked to share it with their members. Between the dates of March 30, 2015 and May 5, 2015, 30 Internet and 238 face-to-face, a total of 268 valid survey forms were collected. Survey questionnaire forms that were applied face-to-face were distributed during the same dates to individuals that volunteered in the student clubs during busy hours. With interviews generally conducted between 3:00 p.m. and 5:00 p.m. that lasted for two hours, the process was completed. Nine survey forms were excluded from the sample, since they contained more than $10 \%$ lost data. The sample size of 268 represents an appropriate sample size based on the sampling calculation formula (Ural \& Kılıç, 2011, p. 49).

Before the analysis of the data obtained from the survey, field application, reliability, and sample sufficiency tests were conducted for the recreation experience scale. After the suitability of the scale for factor analysis and reliability were evidenced, three basic analyses were planned to obtain the main findings of the study. First order were the descriptive analyses conducted on demographical date to demonstrate the characteristics of the sample. In the second phase, correlation analysis was conducted to determine the relationship between the activity participation frequencies of the students with respect to the categories and the experiences they gained. And finally, regression analysis was conducted to determine the effects of the recreational experiences of students on the intent to continue the activity.

\section{Factor Analysis}

Factor analysis was conducted to test the structural validity and reliability of the recreation experience scale designed for the study. Suitability of the data set for factor analysis and the consistency of the variables and expressions of the factor structure obtained were tested using Kaiser-Meyer-Olkin (KMO) and 
Bartlett Sphericity Test. KMO value for the recreation experience scale was 0.915 , Bartlett Sphericity Test result was $p=0.000$. While a KMO value of over 0.60 shows that sample size for data set factor analysis is at a good level and sufficient, a Bartlett Sphericity Test's $p$ value of less than 0.05 demonstrates that expressions and factors are consistent and with sufficient correlation (Alpar, 2011, p. 286). After the suitability of the data set for factor analysis was determined, factor analysis was conducted and analysis results are visualized in Table 1.

Table 1

Exploratory Factor Analysis for Recreation Experience Scale

\begin{tabular}{|c|c|c|c|c|c|c|c|c|}
\hline \multirow{2}{*}{ Recreation experience } & \multicolumn{7}{|c|}{ Scale } & \multirow{2}{*}{$\begin{array}{l}\text { Item total } \\
\text { correlation } \\
\text { score }\end{array}$} \\
\hline & 1 & 2 & 3 & 4 & 5 & 6 & 7 & \\
\hline \multicolumn{9}{|l|}{ Physical exercise and leisure } \\
\hline 19. I did physical exercise. & 0.858 & & & & & & & 0.628 \\
\hline 20. I physically kept fit. & 0.814 & & & & & & & 0.724 \\
\hline 21. I physically relaxed. & 0.785 & & & & & & & 0.678 \\
\hline 22. I physically rested. & 0.729 & & & & & & & 0.647 \\
\hline \multicolumn{9}{|l|}{ Learning about new and different objects and people } \\
\hline 9. I learned about new things. & & 0.816 & & & & & & 0.686 \\
\hline 10. I experienced new and different things. & & 0.763 & & & & & & 0.681 \\
\hline 8. I observed other people in the university. & & 0.756 & & & & & & 0.607 \\
\hline 7. I met new and different people. & & 0.561 & & & & & & 0.647 \\
\hline \multicolumn{9}{|l|}{ Leadership and insight } \\
\hline 16. I led other individuals. & & & 0.758 & & & & & 0.507 \\
\hline 15. I helped direct the activities of others. & & & 0.664 & & & & & 0.619 \\
\hline 17. I developed my spiritual aspect. & & & 0.629 & & & & & 0.561 \\
\hline 18. I thought over my personal values. & & & 0.593 & & & & & 0.618 \\
\hline 14. I shared with others what I learned. & & & 0.462 & & & & & 0.649 \\
\hline \multicolumn{9}{|l|}{ Achievement } \\
\hline 4. I saw what I could do. & & & & 0.749 & & & & 0.633 \\
\hline 2. I demonstrated to others what I could do. & & & & 0.713 & & & & 0.531 \\
\hline 3. My skills and abilities improved. & & & & 0.672 & & & & 0.663 \\
\hline 1. My self-confidence improved. & & & & 0.549 & & & & 0.713 \\
\hline \multicolumn{9}{|l|}{ Escape from personal and social pressures } \\
\hline $\begin{array}{l}25 \text {. I left behind my daily responsibilities albeit only } \\
\text { for a while. }\end{array}$ & & & & & 0.714 & & & 0.505 \\
\hline 23. I got rid of my stress. & & & & & 0.707 & & & 0.571 \\
\hline 26. I had the opportunity to change my routine life. & & & & & 0.638 & & & 0.531 \\
\hline 24. I rested my mind. & & & & & 0.622 & & & 0.622 \\
\hline \multicolumn{9}{|l|}{ Learning about culture, arts, and nature } \\
\hline 12. I learned more about culture. & & & & & & 0.823 & & 0.572 \\
\hline 13. I learned more about arts. & & & & & & 0.646 & & 0.492 \\
\hline 11. I learned more about nature. & & & & & & 0.605 & & 0.503 \\
\hline \multicolumn{9}{|l|}{ Human relations } \\
\hline 6. I was with people who shared values with me. & & & & & & & 0.727 & 0.575 \\
\hline 5. I spent good times with my group friends. & & & & & & & 0.626 & 0.608 \\
\hline Cronbach Alpha (Reliability coefficients) & 0.916 & 0.889 & 0.814 & 0.857 & 0.797 & 0.718 & 0.839 & 0.942 \\
\hline Variance explained & $14.2 \%$ & $13.4 \%$ & $11.0 \%$ & $9.8 \%$ & $9.3 \%$ & $7.7 \%$ & $7.3 \%$ & $72.74 \%$ \\
\hline
\end{tabular}


Although the dimensions within REP scale pool matched as a result of the factor analysis, expressions on "leadership" and "insight" dimensions categorized under different topics were collected under a singe factor. Leaders having insight that indicates gaining new information and awareness on their proficiency, especially in group-based recreation activities, plays a significant role in their understanding of the group dynamics and ability to mobilize individuals. Thus, it was decided to name leadership and insight dimensions as an integrated one single dimension, as "leadership and insight."

\section{Findings}

Demographical questions directed to the participants in the study included questions on gender, age, and duration of experience in recreational activities they have participated. The demographical information displayed in Table 2 demonstrates that $42.91 \%(n=115)$ of 268 participating students were female, and $55.97 \%(n=150)$ were males. Eighty-three point five three percent $(n=224)$ were between the ages of 18 and $23,15.30 \%(n=41)$ were 24 or older. Experience time-span of students in recreational activities changed between one and 10 years. Thus, vast majority of the students $(85.82 \% ; n=230)$ participated in recreational activities for 1-3 years, while $10.07 \%(n=27)$ had an experience of 5-11 years. The findings of the study on recreational activities are presented under two topics below.

\section{Categories of Recreation and Preference Frequencies}

The rates of students preferring different recreational activities show that they preferred social recreation activities the most (72.76\%), followed by cultural (72.26\%), artistic (70.52\%), and physical (60.82\%) recreational activities. Similar to preference rates, the participation frequencies of students could be ordered as social (2.46), artistic (2.36), cultural (2.33), and physical (1.96) respectively, based on activity categories. Thus, the students preferred social activities, such as social responsibility activities, and meetings and parties; artistic activities, such as activities that develop manual skills, and dance and movies; cultural activities, such as activities that improve and test knowledge and skills, and excursions and touristic travel more. They have participated less in physical activities, such as mountain sports, sea and pool related activities, and basketball, volleyball and tennis (see Table 2).

Table 2

Recreational Categories and Students' Preference Frequencies

\begin{tabular}{lllll}
\hline Recreation categories & $N$ & Rate of preference (\%) & Mean & $S d$. \\
\hline Social recreation & 195 & 72.76 & 2.46 & 0.86 \\
Cultural recreation & 194 & 72.26 & 2.33 & 0.77 \\
Artistic recreation & 189 & 70.52 & 2.36 & 0.87 \\
Physical recreation & 163 & 60.82 & 1.96 & 0.68 \\
\hline
\end{tabular}

\section{Testing the Hypotheses}

The first hypothesis determined in the study was: H1: "There is a significant relationship between the recreation categories the students participated and the experiences they gained." The relationship between the participation in activities grouped under four categories of physical, social, artistic, and cultural, and the experience dimension was tested with correlation analysis in the study.

Analysis results not reflect a significant relationship between physical participation in recreational activities and experience dimensions. In other words, as the frequency of participation in physical recreational 
activities of students increased, an increase was not observed in their experiences. However, a positive increase in all experience dimensions was observed based on the increase in the frequency of participation in social recreation activities. Thus, an increase of 0.26 in "achievement" experiences of the students; 0.18 in "human relations" experiences; 0.27 in "learning about new and different objects and people" experiences; 0.15 in "learning about nature, culture, and arts" experiences; 0.27 in "leadership and insight" experiences; 0.17 in "physical exercise and leisure" experiences; and 0.12 in "escape from personal and social pressures" experiences were observed. These results show that by increasing the participation of students in social activities, their recreational experiences could as well be improved (see Table 3). The correlation analysis also demonstrated that there was a positive relationship between the frequency of participation in artistic and cultural activities and the experiences gained.

Analysis results showed that, based on the participation of students in artistic activities, an increase of 0.15 in "learning about nature, culture and arts" experiences; and 0.16 in "escape from personal and social pressures" experiences were observed. Finally, based on the participation frequency of the students in cultural activities, an increase of 0.13 in "achievement" experiences of the students; 0.16 in "learning about nature, culture, and arts" and "physical exercise and leisure" experiences; and 0.15 in "escape from personal and social pressures" experiences were observed.

Table 3

Relationship Between Participation in Different Recreational Activities and Experiences

\begin{tabular}{|c|c|c|c|c|c|c|c|c|}
\hline \multicolumn{2}{|c|}{$\begin{array}{l}\text { Participation } \\
\text { frequencies based } \\
\text { on recreation } \\
\text { activity categories }\end{array}$} & Achievement & $\begin{array}{l}\text { Human } \\
\text { relations }\end{array}$ & $\begin{array}{l}\text { Learning about } \\
\text { new and different } \\
\text { objects and people }\end{array}$ & $\begin{array}{l}\text { Learning } \\
\text { about nature, } \\
\text { culture, and } \\
\text { arts }\end{array}$ & $\begin{array}{l}\text { Leadership } \\
\text { and insight }\end{array}$ & $\begin{array}{l}\text { Physical } \\
\text { exercise and } \\
\text { leisure }\end{array}$ & $\begin{array}{l}\text { Escape from } \\
\text { personal and } \\
\text { social } \\
\text { pressures }\end{array}$ \\
\hline \multirow{3}{*}{ Physical } & $R$ & -0.019 & -0.007 & -0.006 & 0.078 & 0.025 & 0.106 & 0.068 \\
\hline & $P$ value & 0.751 & 0.912 & 0.918 & 0.201 & 0.679 & 0.084 & 0.264 \\
\hline & $N$ & 268 & 268 & 268 & 268 & 268 & 267 & 268 \\
\hline \multirow{3}{*}{ Social } & $R$ & $0.263^{* *}$ & $0.182^{* *}$ & $0.271^{* *}$ & $0.150^{*}$ & $0.272^{* *}$ & $0.170^{* *}$ & $0.126^{*}$ \\
\hline & $P$ value & 0.000 & 0.003 & 0.000 & 0.014 & 0.000 & 0.005 & 0.039 \\
\hline & $N$ & 268 & 268 & 268 & 268 & 268 & 267 & 268 \\
\hline \multirow{3}{*}{ Artistic } & $R$ & -0.007 & 0.025 & 0.062 & $0.152^{*}$ & 0.023 & 0.118 & $0.160^{* *}$ \\
\hline & $P$ value & 0.909 & 0.679 & 0.309 & 0.013 & 0.704 & 0.055 & 0.009 \\
\hline & $N$ & 268 & 268 & 268 & 268 & 268 & 267 & 268 \\
\hline \multirow{3}{*}{ Cultural } & $R$ & $0.132^{*}$ & 0.063 & 0.110 & $0.167^{* *}$ & 0.103 & $0.167^{* *}$ & $0.157^{* *}$ \\
\hline & $P$ value & 0.030 & 0.302 & 0.073 & 0.006 & 0.091 & 0.006 & 0.010 \\
\hline & $N$ & 268 & 268 & 268 & 268 & 268 & 267 & 268 \\
\hline
\end{tabular}

Note. ${ }^{*}$ Correlation is significant at the 0.05 level; and ${ }^{* *}$ correlation is significant at the 0.01 level.

Arithmetic mean and standard deviation values for the expressions of the students favoring the continuation in recreational activities were calculated as well. Analysis results demonstrated that students intent to continue $(3.18=$ Agree) the recreational activities that they participated in the club in the future as well.

In addition, regression analysis was conducted to test the $\mathrm{H} 2$ hypothesis: "Recreational experiences of the students are effective on the intent to continue the same recreation activities after graduation" in the study. The regression equation was found to be statistically significant $(F=103.42, p<0.001)$ and the analysis results are displayed in Table 4. Table 4 shows that the factors of "leadership and insight" and "human relations" were effective on the intent to continue $(p<0.05)$. The effect of experience dimensions on the intent to continue was $44.2 \%\left(R^{2}=0.442\right)$. In brief, students' intention to continue a recreational activity is determined by the 
experiences they gained from these recreational activities. The independent variable with the highest $\beta$ value has the most significant effect relatively (Büyüköztürk, 2012, p. 105). Thus, it was determined that the experience dimension that had the most significant effect on the intent of the students to continue the recreational activity was "leadership and insight" $(\beta=0.447)$.

Table 4

The Effect of Recreational Experiences on the Intent to Continue the Recreation

\begin{tabular}{|c|c|c|c|c|c|c|}
\hline \multirow{2}{*}{\multicolumn{2}{|c|}{ Model }} & \multicolumn{2}{|c|}{ Non-standardized coefficient } & \multicolumn{3}{|c|}{ Standardized coefficient } \\
\hline & & $B$ & $S d$. & $B$ & $t$ value & $p$ value \\
\hline \multirow[t]{3}{*}{1} & (Constant) & 0.220 & 0.196 & & 1.123 & 0.263 \\
\hline & Leadership and insight & 0.521 & 0.063 & 0.447 & 8.279 & 0.000 \\
\hline & Human relations & 0.324 & 0.055 & 0.317 & 5.872 & 0.000 \\
\hline
\end{tabular}

Note. $R^{2}=0.442 ; F=103.42 ; p=0.000 ;$ and $\mathrm{VIF}=1.354$.

\section{Conclusions}

Students need experiential conditions that could deploy various motivations, such as entertainment, leisure, self-realization, and interact with others in their spare times. Student clubs in Anadolu University provide an environment of experiences that enrich the school life of the youth of different age and experiences, and help them enjoy the life via physical, social, cultural, and artistic recreational activities. However, continuation of recreational activities after graduation is important for the youth to maintain the social-life balance throughout their lives in the future. The decision of the students to continue recreational activities in the future as well is shaped by the recreational experiences they have at school. Thus, the main objective of the study was to determine effects of experiences of Anadolu University students gained as a result of recreation activities they participated on their intention to continue these recreation activities in the future. Furthermore, the study aimed to determine the participation frequencies of students in recreation activities based on the categories and the experiences gained from these activities. Validity and reliability tests demonstrated that REP scale could be used for the measurement of recreational experiences.

There are studies in literature that indicate frequent participation in social recreational activities provide group skills, enable students to direct others and to lead, and provide experiences, such as self-confidence, achievement, learning new and different subjects (Driver, 1983) for the students. Findings of the study, parallel to the findings in the literature, indicated that, when students participated more frequently in social recreation activities, there was a significant improvement in all recreational experience dimensions. In the study, as the participation frequency of the students in all of the social, cultural, and artistic categories increased, an increase was observed in "learning about nature, culture, and arts" and "escape from personal and social pressures" experiences. While the students accomplished experimental, cognitive and social learning as they participated in such recreational activities (Köktaş, 2004), they also put a distance between them and the routine of their lives, easing the mental pressure on themselves. In other words, by participating in social, cultural, and artistic recreational activities more, students could benefit more from the above-mentioned advantages.

Furthermore, in the study, the relationship between the frequency of participation in activities and achievement dimension was evaluated and it was observed that as the frequency of the students participating in activities in the cultural category increased, their "achievement" experiences increased as well. In addition, since cultural category includes physical mobility activities, such as excursions and touristic travel, it was determined 
that as the students participated in cultural activities, their "physical exercise and leisure" experiences increased as well. Thus, as the frequency of the students to participate in activities in the social, cultural, and artistic categories increased, the experiences they gained increased as well. Therefore, it is necessary for the clubs to organize frequent activities to increase recreational experiences of the students and encourage students to participate in these activities. It could be recommended that, to be able to achieve this goal, the clubs should determine which types of activities the students prefer, should provide appropriate recreational spaces; and the students should plan their programs to participate in recreation activities as much as possible.

It was observed in the study that the intent of the students to continue recreation activities is largely determined by the experiences they had as a result of the recreational activities. Thus, "leadership and insight" and "human relations" experiences of the students was effective on the intent to continue the recreational activities in the future. Previous studies have also indicated that the recreational experiences, which the individuals had at early ages, were effective on the continuation of these experiences in the future (Wang, Wu, \& Wu, 2013, p. 68). Aarnio, Winter, Peitonen, Kujala, and Kaprio (2002, p. 179) reported that youngsters continue their outdoor recreational experiences in adulthood, developing a more active lifestyle. Examination of human relations experience context demonstrated that socialization opportunities and friends had significant effects on the participation of students in recreational activities and the experiences they gained (Festeu, 2002; McKenzie, 2011, p. 32; Tercan, 2013, p. 228; Gürbüz \& Henderson, 2013, p. 927). It was determined in the study that the experience dimension, which influenced the intent of the students to continue recreation activities the most, was "leadership and insight."

As a result, it should be stressed that, to train the youth to have a physically, mentally, and socially healthy future, universities should emphasize recreation support applications that provide active recreation opportunities and enable sustainable participation in these activities. Thus, student clubs or student groups share the largest responsibility. Participation in recreational activities should be encouraged (grades or economical) for the culture of recreation to be adapted and sustained and to gain positive experiences from the recreational activities as expected. This study also highlighted the significance of group leadership and human relations in the choice of recreational activities. Therefore, it could be argued that courses that develop leadership and human relations should be included in the programs of Recreation Departments (including Tour Guide Departments) in different faculties in universities.

\section{References}

Aarnio, M., Winter, T., Peitonen, J., Kujala, E. M., \& Kaprio, J. (2002). Stability ofleisure-time physical activity during adolescence: A longitudinal study among 16-, 17-, and 18- year-old Finnish youth. Scandinavian Journal of Medicine and Science in Sports, 12(3), 179-185.

Ajzen, I. (1985). From intentions to action - A theory of planned behavior, action control: From cognition to behavior. Berlin: Springer-Verlag.

Akıncı, M. (2011). Kocaeli ili yüzme kulüplerindeki sporcuların rekreasyon faaliyetlerinin incelenmesi (Examination of the activities of recreational athletes in the provience of Kocaeli swimming clubs) (M.Sc. dissertation, Sakarya University).

Akyol, A., Bilgiç, P., \& Ersoy, G. (2008). Fiziksel aktivite, beslenme ve sağllkl yaşam (Physical activity, nutrition, and wellness). Ankara: Republic of Turkey Ministry of Health.

Alexandris, K., \& Stodolska, M. (2004). The influence of perceived constraints on the attitudes toward recreational sport participation. Society and Leisure, 27(1), 197-217.

Alexandris, K., Kouthourisand, C., \& Girgolas, G. (2007). Investigating the relationships among motivation, negotiation, and alpine skiing participation. Journal of Leisure Research, 39(4), 648-667.

Alpar, R. (2011). Uygulamal çok değişkenli istatistiksel yöntemler (Applied multivariate statistical methods). Ankara: Detay Publishing. 
Aşan, K. (2013). Doğa deneyimleri açık alan rekreasyon güdüleri ve tatil aktivite tercihleri arasındaki ilişkinin belirlenmesi (Determination relationship between nature experience, outdoor recreation motivation and vacation activity preferences) (M.Sc. dissertation, Anadolu University).

Ateca-Amestoya, V., Serrano-del-Rosala, R., \& VeraToscanoa, E. (2008). The leisure experience. Journal of Socio-Economics, $37(1), 64-78$.

Başaran, Ü. (2014). Algılanan müşteri değeri bileşenlerinin davranışsal niyetler üzerindeki etkisi (The effects of perceived customer value components on behavioral intentions) (Ph.D. dissertation, Bülent Ecevit University).

Budruk, M., \& Stanis, W. A. S. (2013). Place attachment and recreation experience preference: A further exploration of the relationship. Journal of Outdoor Recreation and Tourism, 1(2), 51-61.

Büyüköztürk, Ş. (2012). Sosyal bilimler için veri analizi el kitabı istatistik, araştırma deseni spss uygulamaları ve yorum (Handbook of data analyses social science). Ankara: Pegem Publishing.

Driver, B. L. (1983). Master list of items for recreation experience preference scales and domain (Unpublished document, USDA Forest Service, Rocky Mountain Forest and Range Experiment Station, Fort Collins, Co.).

Ekiz, D. (2009). Bilimsel araştırma yöntemleri (Scientific research methods). Ankara: Anı Publishing.

Festeu, D. (2002). Motivational factors that influences students' participation in outdoor activities. Journal of Adventure Education and Outdoor Learning, 2(1), 43-54.

Flood, J. P., \& Parker, C. (2014). Student awareness of university adventure programs: Understanding motivations and constraints. Recreational Sports Journal, 38, 104-117.

Günaydın, M. (2011). K.T.Ü Kanuni Yerleşkesi'ndeki (Trabzon) Öğrencilerin Spor ve Rekreasyon İhtiyaçlarının Saptanması ve Gelişimine Yönelik Yaklaşımların İrdelenmesi (An examination of the approaches towards the determination and development of sports and recreation needs of students on KTU Kanuni Campus (Trabzon)) (M.Sc. dissertation, Karadeniz Teknik University).

Gürbüz, B., \& Henderson, K. (2013). Exploring the meanings of leisure among Turkish university students. Croatian Journal of Education, 15(4), 927-957.

Hazar, A. (2009). Rekreasyon ve animasyon (Recreation and animation). Ankara: Detay Publishing.

Hellier, P. K., Geursen, G. M., Carr, R. A., \& Rickard, J. A. (2003). Customer repurchase intention: A general structural equation model. European Journal of Marketing, 37(11-12), 1762-1800.

Hsieh, T. (2007). Recreational motivation, sensation seeking, and recreational involvement of Taiwans' adventure recreation participants (Ph.D. diss., University of the Incarnate Word).

Jensen, C. R., \& Guthrie, S. P. (2005). Outdoor recration in America. Illinois, USA: Human Kinetics.

Kaba, İ. C. (2009). Türkiye'deki Üniversitelerde Kampüs Rekreasyonu'nun Mevcut Durumu ve Kampüs Rekreasyon Modellemesi (Current situation of campus recreation in the Turkish universities and the campus recreation modeling) (Ph.D. dissertation, Marmara University).

Karaküçük, S. (1997). Rekreasyon boş zaman değerlendirme: Kavram, kapsam ve bir araştırma (Recreation, spending leisure time: Concept, scope, and research). Ankara: Turhan Publishing.

Karaküçük, S. (2008). Rekreasyon boş zaman değerlendirme (Recreation and leisure). Ankara: Gazi Publishing.

Kaur, G., \& Gupta, S. (2012). Consumers' behavioral intentions toward self-service technology in the emerging markets. Journal of Global Marketing, 25(5), 241-261.

Kim, M., Chelladurai, P., \& Trail, G. T. (2007). A model of volunteer retention in youth sport. Journal of Sport Management, 21, 151-171.

Kleiber, D. A., Walker, G. J., \& Mannel, R. C. (2011). A social psychology of leisure. State College, P.A.: Venture Publishing, Inc..

Kouthouris, C. (2009). An examination of the relationships between motivation, involvement, and intention to continuing participation among recreational skiers. International Journal of Sport Management, Recreation, and Tourism, 4, 1-19.

Kozak, M. (2014). Bilimsel araştırma: Tasarım, yazım ve yayım teknikleri (Scientific research: Design, writing, and publishing techniques). Ankara: Detay Publishing.

Kozak, M. A., \& Çakır, O. (2012). A conceptual study on recreational leadership. Paper presented at The 6th World Conference for Graduate Research in Tourism, Hospitality, and Leisure, Fethiye, Turkey.

Kozak, M. A., \& Metin, T. (2014). Turistik rekreasyon planlamasında rekreasyonel firsat dağılımı yönteminin kullanımı (Utilization of recreational opportunities spectrum's method in planning touristic recreation). International Journal of Human Sciences, 11(1), 1114-1125. 
Kozak, M. A., \& Yüncü, D. K. (2008). Rekreasyonel liderlik ve grup dinamikleri (Recreational leadership and group dynamics). Prof. Dr. Fermani Maviş: Memory book.. Eskişehir: Anadolu UniversityPublishing.

Köktaş, K. Ş. (2004). Rekreasyon boş zaman değerlendirme (Recreation, spending leisure time). Ankara: Nobel Publishing.

Kraus, R. G. (1985). Recreation program planning today. London: Scott Foresman and Company.

Leitner, M. J., \& Leitner, S. F. (2012). Leisure enhancement. Urbana: Sagamore Publishing.

Manfredo, M. J., Driver, B., \& Tarrat, M. A. (1996). Measuring leisure motivation: A meta analysis of the recreation preference scales. Journal of Leisure Research, 28(3), 188-213.

McCool, S. (2006). Managing for visitor experiences in protected areas: Promising opportunities and fundamental challenges. Protected Areas Programme Parks, 16(2), 3-9.

McKenzie, E. (2011). Recreation experience preference among first-year college students (M.Sc. dissertation, Oklahoma State University).

McLean, D. J., Hurd, A. R., \& Rogers, N. B. (2005). Kraus' recreation and leisure in modern society. Boston: Jones and Bartlett Publishers.

Müderrisoğlu, H., Yerli, Ö., Turan, A. A., \& Duru, N. (2005). ROS (Rekreasyonel Fırsat Dağılımı) yöntemi ile Abant Tabiat Parkı'nda kullanıcı memnuniyetinin belirlenmesi (Determination of user satisfaction in Abant Nature Park by using ROS method). Tarım Bilimleri Dergisi, 11(4), 397-405.

Müftüler, M. (2008). Muğla üniversitesi'nde okuyan öğrencilerin çoklu zekâ alanlarına göre rekreasyon tercihlerinin belirlenmesi (Examining recreation preferences of the students in Muğla University according to their multiple intelligence areas) (M.Sc. dissertation, Muğla University).

Nikolaeva, E. A. (2012). Exploring visitor experiences within the going-to-the-sun corridor of Glacier National Park (M.Sc. dissertation, University of Montana Missoula).

Oliver, R. L. (1997). Satisfaction: A behavioral perspective on the consumer (2nd ed.). New York, N.Y.: M.E. Sharpe, Inc.

Patterson, I., \& Pegg, S. (2009). Marketing the leisure experience to baby boomers and older. Journal of Hospitality Marketing and Management, 18, 254-272.

Shores, K., \& Scott, D. (2007). The relationship of individual time perspective and recreation experience preferences (Ph.D. dissertation, Texas A \& M University).

Tribe, J. (1995). The economics of leisure and tourism: Environments, markets, and impacts. Oxford: Butterworth-Heinemann Ltd..

Ural, A., \& Kılıç, İ. (2011). Bilimsel araştırma süreci ve SPSS ile veri analizi (Scientific research process and data analysis with SPSS). Ankara: Detay Publishing.

Volo, S. (2009). Conceptualizing experience: A tourist based approach. Journal of Hospitality Marketing and Management, 18, 111-126.

Wang, W., Wu, C., \& Wu, C. (2013). Early-life outdoor experiences and involvement in outdoor recreational activities in adulthood: A case study of visitors in Da-Keng. Taiwan Journal of Quality Assurance in Hospitality and Tourism, 14, 66-80.

Weber, D., \& Anderson, D. (2011). Contact with nature: Recreation experience preferences in Australian Parks. Annals of Leisure Research, 13(1-2), 46-69. 